\title{
Pengaruh Struktur Kepemilikan dan Struktur Dana Pihak Ketiga terhadap Pengungkapan Tata Kelola pada Perbankan Syariah di Indonesia
}

\author{
Farah Dwi Puspitasari $^{1)}$, Citra Sukmadilaga ${ }^{2)}$, Indri Yuliafitri $^{3)}$ \\ 1), 2), 3) Fakultas Ekonomi dan Bisnis, Universitas Padjadjaran, Bandung \\ Email:farahdwip@gmail.com ${ }^{l)}$, citra.sukmadilaga@unpad.ac.id ${ }^{2}$,indri.yuliafitri@unpad.ac.id ${ }^{3)}$
}

\begin{abstract}
ABSTRAK
Penelitian ini bertujuan untuk menguji pengaruh struktur kepemilikan dan struktur dana pihak ketiga terhadap pengungkapan tata kelola pada perbankan syariah di Indonesia. Variabel dependen yang digunakan dalam penelitian ini adalah pengungkapan tata kelola yang diukur dengan Islamic Corporate Governance (ICG). Variabel independen dalam penelitian ini adalah struktur kepemilikan yang diukur dengan kepemilikan Blockholder dan struktur dana pihak ketiga yang diukur dengan Restricted Profit Sharing Investment Account (RPSIA). Populasi dalam penelitian ini adalah perbankan syariah yang terdaftar di Otoritas Jasa Keuangan (OJK) periode 2012-2018. Sampel dalam penelitian ini adalah 11 bank syariah Metode analisis data yang digunakan dalam penelitian ini adalah regresi linier berganda. Hasil penelitian menunjukkan bahwa: (1) struktur kepemilikan berpengaruh positif signifikan terhadap pengungkapan tata kelola. (2) struktur dana pihak ketiga berpengaruh positif signifikan terhadap pengungkapan tata kelola.
\end{abstract}

Kata Kunci: Struktur Kepemilikan, Struktur Dana Pihak Ketiga, Pengungkapan Tata Kelola, Bank Syariah

\section{Pendahuluan}

Perkembangan institusi keuangan Islam khususnya bank syariah mulai meningkat dari tahun ke tahun. Bank syariah mulai berkembang di Indonesia pasca disetujuinya UU No.10 tahun 1998, yang mengatur dengan rinci landasan hukum serta jenis-jenis usaha yang dapat dioperasikan dan diimplementasikan oleh bank syariah. Hal lain yang memicu tumbuhnya bank syariah adalah Fatwa MUI tentang haramnya bunga bank. Dengan adanya fatwa tersebut jelas memperkuat posisi bank syariah sebagai satu-satunya alternatif bagi kaum muslimin untuk menitipkan uangnya. Hal ini dikarenakan pandangan masyarakat yang menganggap bahwa bank syariah adalah lembaga keuangan yang telah bebas dari praktik riba.

Sebagai salah satu entitas bisnis yang berada di bawah payung negara kesatuan Indonesia, bank syariah pun dituntut untuk menerapkan Good Corporate Governance (GCG). Penerapan GCG di bank syariah menjadi penting mengingat bank syariah merupakan bank yang menggunakan prinsip profit sharing di mana keuntungan dibagi bersama antara bank dan nasabah. Pedoman GCG yang telah dikeluarkan oleh Komite Nasional Kebijakan Governance (KNKG) mengikat seluruh entitas bisnis, baik yang konvensional maupun syariah. Hal ini dilakukan sebagai upaya pemerintah untuk menciptakan iklim dunia usaha yang sehat.

Salah satu pengungkapan yang dilaporkan dalam laporan tahunan adalah pengungkapan pelaksanaan tata kelola perusahaan (corporate governance). Lemahnya implementasi tata kelola perusahaan akan menyebabkan perusahaan tidak dapat mencapai tujuannya berupa profit yang maksimal, tidak mampu mengembangkan perusahaan dalam persaingan bisnis, dan tidak dapat memenuhi berbagai kepentingan stakeholders (Ruru, 2002). Kusumawati (2007) berpendapat bahwa investor bersedia membayar premi yang lebih tinggi untuk perusahaan yang menerapkan dan mengungkapkan informasi. Tata kelola perusahaan di dalam laporan tahunan. Pelaksanaan tata kelola perusahaan dan pengungkapannya dapat memfasilitasi dan meningkatkan kinerja perusahaan, membatasi manajer menyalahgunakan sumber daya perusahaan, dan perilaku oportunistik manajer dapat diawasi (Bhuiyan \& Biswas, 2007).

Perkembangan perbankan syariah sejatinya memang masih jauh dari harapan. Melihat penduduk muslim yang banyak, nyatanya bukan menjadi jaminan perbankan syariah berkembang dengan cepat. Bahkan, kinerja keuangan bank syariah belum sebaik bank konvensional. Masalah tata kelola ini memang menjadi salah satu masalah selain karena lemahnya kondisi internal bank, lemahnya manajemen bank, moral dari Sumber Daya Manusia (SDM), dan pengawasan yang belum efektif dari Bank Indonesia (Ferdyant et al., 2014).

Lembaga Pengembangan Perbankan Indonesia (LPPI) melakukan survei terkait dengan praktik tata kelola perusahaan yang baik (Good Corporate Governance) di industri perbankan yang menunjukkan bahwa penerapan GCG di perbankan terlihat mulai mengendur ketika maraknya pembobolan dana ataupun praktik fraud yang telah menimpa perbankan (Nisaputra, 2018).

Struktur kepemilikan menggambarkan penyebaran komposisi saham pihak- pihak yang memiliki kekuasaan untuk menentukan kebijakan sebagai pedoman manajer dalam mengelola perusahaan (Saleh et al., 2009; Hartini, 2016). Perbedaan dalam proporsi saham yang dimiliki oleh investor dapat mempengaruhi tingkat kelengkapan pengungkapan oleh perusahaan. Semakin banyak pihak yang membutuhkan informasi tentang perusahaan, maka semakin detail pula pengungkapan yang dilakukan oleh perusahaan (Nabor \& Suardana, 2014). 
Selama tahun 2011 sampai 2016 perkembangan Dana Pihak Ketiga (DPK) menunjukkan perkembangan yang kurang stabil. Perkembangan DPK dari tahun 2011 sampai 2014 secara nominal mengalami kenaikan tetapi prosentase kenaikan DPK dari tahun 2011 sampai 2014 mengalami penurunan. Fluktuasi DPK lebih banyak dipengaruhi kondisi makro ekonomi, seperti tingkat pendapatan masyarakat, tingkat inflasi, nilai tukar dan kondisi investasi. Faktor internal seperti tingkat bagi hasil, kinerja keuangan bank yang tidak banyak berpengaruh terhadap keputusan mitra untuk melakukan investasi dalam bentuk tabungan, deposito dan giro (Sudarsono, 2017).

Bank-bank syariah merupakan komponen penting dari pengembangan sistem keuangan Islam dengan cara mengumpulkan dana melalui Profit Sharing Investment Account (PSIA). PSIA menggantikan simpanan dalam perbankan konvensional, karena bank syariah harus mematuhi syariah, yang tidak mengizinkan aktivitas apa pun yang melibatkan riba, atau bunga. Para deposan yang disebut sebagai Investment Account Holders (IAH) menerima bagian keuntungan mereka dan menanggung kerugian yang diakibatkan.

Menurut penelitian yang dilakukan oleh Grassa (2018) dikatakan bahwa tingkat pengungkapan tata kelola perusahaan meningkat dengan bank syariah dengan konsentrasi PSIA yang lebih tinggi, ukuran bank syariah, usia bank, bank terdaftar, dan indeks transparansi Negara. Penelitian-penelitian sebelumnya telah membahas konflik kepentingan yang ada antara pemegang saham dan pemegang PSIA. Memang, PSIA mendorong manajer bank syariah untuk mengambil lebih banyak risiko dan beroperasi dengan modal lebih sedikit (Visser, 2009). Menurut Archer et al. (2010), PSIA merupakan sumber utama pendanaan bank syariah. PSIA mewakili sebagian besar liabilitas bank syariah dan sebagai pemegang ekuitas. Mereka berbagi keuntungan dan kerugian dengan bank (Archer et al., 2010). Bagaimanapun, mereka tidak mempunyai jaminan atau suara yang kuat untuk melindungi sahamnya dari kesalahan manajemen atau perilaku pemegang saham yang oportunis. Selain itu, mereka hanya menggunakan informasi yang diungkapkan dalam laporan tahunan untuk membuat keputusan. Pemegang dari PSIA bisa menjadi sumber dari risiko moral dalam kasus kebangkrutan. Karena bank tidak dibatasi untuk membayar dan melindungi pemegang PSIA karena prinsip bagi hasil. Bank syariah sebagai lembaga keuangan yang berbasis ekuitas yang didominasi oleh pemegang saham ekuitas dan pemegang PSIA, sangat mudah terpapar pada risiko besar dari penarikan dana yang mengancam posisi mereka.

Penelitian tentang pengungkapan tata kelola perusahaan telah dilakukan di berbagai negara dan berbagai jenis perusahaan. Lengkap atau tidaknya pengungkapan tata kelola perusahaan dalam laporan tahunan ternyata dipengaruhi oleh beberapa faktor. Faktor-faktor yang mempengaruhi pengungkapan tata kelola perusahaan dalam penelitian ini meliputi struktur kepemilikan dan dana pihak ketiga.

\section{Tinjauan Literatur Agency Theory}

Pada tahun 1976, Jensen dan Meckling sebagai yang pertama membahas Agency theory. Menurut Jensen dan Meckling, hubungan keagenan adalah kontrak antara manajer (agent) dengan investor (principal) dalam sebuah perusahaan. Pemisahan status antara investor dan manajer yang akan menimbulkan suatu masalah (agency problem) karena adanya benturan kepentingan antara keduanya karena masing-masing individu cenderung untuk mementingkan diri sendiri adalah inti dari hubungan keagenan ini.

Adanya perbedaan kepentingan antara principal (pemegang saham) dan agent (manajer) dapat menimbulkan sebuah informasi asymetri (kesenjangan informasi). Setiap pihak berusaha untuk memperbesar keuntungan bagi diri mereka sendiri. Dalam hal ini, manajer dapat melakukan tindakan kecurangan (fraud) untuk memanipulasi laba, agar kompensasi ekonomi yang diberikan oleh principal menjadi semakin besar. Tindakan-tindakan seperti memanipulasi laba inilah yang menjadi pentingnya adanya pengendalian internal dan struktur tata kelola perusahaan (governance structure) (Wibowo \& Rohman, 2013).

\section{Corporate Governance}

Tata kelola perusahaan atau corporate governance merupakan suatu sistem yang terdiri dari sekumpulan struktur, prosedur, dan mekanisme yang dirancang untuk pengelolaan perusahaan dengan berlandaskan prinsip akuntabilitas yang dapat meningkatkan nilai perusahaan dalam jangka panjang (Onasis \& Robin, 2016; Yanti, 2016; Patmawati, 2017; Eliana \& Wahyuni, 2019).

Adanya corporate governance muncul disebabkan terjadinya pemisahan antara kepemilikan dengan pengendalian perusahaan atau dikenal dengan istilah masalah keagenan. Permasalahan keagenan dalam hubungannya antara pemilik modal dengan manajer adalah bagaimana sulitnya pemilik dalam memastikan bahwa dana yang ditanamkan tidak diambil alih atau diinvestasikan pada proyek yang tidak menguntungkan sehingga tidak mendatangkan return. Corporate governance diperlukan untuk mengurangi permasalahan keagenan antara pemilik dan manajer.

\section{Islamic Corporate Governance (ICG)}

Saat ini tidak ada pemahaman terpadu yang jelas tentang Good Corporate Governance di bawah hukum keuangan Islam; model ICG diusulkan dengan merekonsiliasi tujuan hukum Syariah dengan model stakeholder tata kelola perusahaan. Model ini layak karena penekanan bahwa hukum Syariah menempatkan pada properti dan hak kontraktual keuangan Islam (Bhatti dan Bhatti, 2010; Armereo, 2015).

Menurut El Junusi (2012) yang membedakan antara implementasi Good Corporate Governance (GCG) pada perbankan syariah dan konvensional terletak pada shariah compliance (kepatuhan pada syariat Islam). Sedangkan prinsip-prinsip transparansi, kejujuran, kehati-hatian, dan 
kedisiplinan merupakan prinsip universal yang juga terdapat dalam aturan GCG konvensional.

\section{Struktur Kepemilikan}

Struktur kepemilikan merupakan pemisahan antara pemilik perusahaan dan manajer perusahaan (Oetari, Gustini, \& Permata, 2018). Pemilik atau pemegang saham adalah pihak yang menyertakan modal ke dalam perusahaan, sedangkan manajer adalah pihak yang ditunjuk pemilik dan diberi kewenangan mengambil keputusan dalam mengelola perusahaan, dengan harapan manajer bertindak sesuai dengan kepentingan pemilik (Sudana, 2011).

Struktur kepemilikan terdiri dari kepemilikan blockholder dan pemegang saham pengendali. Kepemilikan blockholder adalah kepemilikan saham yang diukur oleh seberapa besar fraksi saham yang dimiliki termasuk kepemilikan saham oleh pemilik yang besarnya lebih dari 5\% baik saham yang dipegang oleh manajemen, direktur dan keluarganya, saham yang dipegang oleh perusahaan lain atau sering disebut institusional, saham yang dipegang pemerintah atau saham yang dipegang oleh dana pensiun (Thomson et al., 2006).

Menurut PBI No. 5/25/2003 tentang Penilaian Kemampuan dan Kepatuhan, blockholders yang memiliki saham dalam jumlah yang besar dalam bank (large shareholders) disebut sebagai Pemegang Saham Pengendali (PSP). Untuk mengatur masalah kepemilikan bank, BI mengeluarkan peraturan bahwa setiap Bank, dipegang oleh satu Pemegang Saham Pengendali. Untuk menjadi pemegang saham pengendali harus memenuhi syarat dan ketentuan yang dikeluarkan oleh Bank Indonesia salah satunya harus lolos dalam penilaian kemampuan dan kepatuhan (fit and proper test) di antaranya penilaian integritas kompetensi dan kelayakan keuangan (Peraturan Bank Indonesia No. 5/25/PBI/2003 tentang Penilaian Kemampuan dan Kepatuhan).

\section{Dana Pihak Ketiga}

Penghimpunan dana di bank syariah menggunakan instrumen yang sama dengan bank konvensional yaitu Giro, Tabungan dan Deposito. Bedanya, dalam bank syariah terdapat varian akad yang berbeda dalam setiap instrumennya, dengan tujuan kontrak perjanjian antara nasabah dan bank syariah menjadi transparan dan jelas. Menurut Arifin (2006), Dana Pihak Ketiga adalah dana yang diperoleh dari masyarakat, dalam arti masyarakat sebagai individu, perusahaan, pemerintah, rumah tangga, koperasi, yayasan, dan lain-lain baik dalam mata uang rupiah maupun dalam valuta asing. Pada sebagian besar atau setiap bank, dana masyarakat ini merupakan dana terbesar yang dimiliki. Hal ini sesuai dengan fungsi bank sebagai penghimpun dana dari masyarakat.

\section{Profit Sharing Investment Account (PSIA)}

Dalam perbankan Islam, time deposit atau rekening deposito disebut dengan istilah investment account. Disebut demikian karena dana yang dihimpun oleh bank dalam bentuk deposito atau time deposit digunakan oleh bank untuk membiayai investasi. Investment account dianggap sebagai instrumen keuangan yang utama untuk menarik dana bagi sistem perbankan syariah (Sjahdeini, 2014).

Bank syariah menghindari berurusan dengan bunga dengan mengganti deposito berbunga dengan Profit Sharing Investment Account (PSIA) yang umumnya didasarkan pada kontrak mudharabah. Di bawah kontrak tersebut, bank syariah disebut mudarib, yang merupakan pihak yang mengelola dana. Sedangkan sang depositor atau disebut dengan Investment Account Holder (IAH) yang bertindak sebagai penyedia modal, juga dikenal sebagai rabb al-mal. Mitra-mitra ini berbagi laba sesuai dengan rasio bagi hasil yang ditentukan dalam perjanjian. Namun, kerugian ditanggung semata-mata oleh IAH dan bank tidak akan mendapatkan imbalan atas upaya mereka. Akibatnya, PSIA menjadi tidak "bermodal pasti" (Gambling \& Karim, 1991; Archer \& Karim, 2009; Suandi, 2017). Struktur kemitraan ini memungkinkan bank-bank syariah untuk melakukan bisnis sambil mematuhi perintah Islam.

Terdapat dua jenis PSIA yaitu restricted PSIA dan unrestricted PSIA. Kontrak mudharabah untuk restricted PSIA menentukan batasan-batasan tertentu yang membatasi hak istimewa bank syariah terkait dengan penggunaan dana tersebut bersama dengan sumber keuangan lainnya. Jenis PSIA yang kedua, yaitu unrestricted PSIA adalah yang paling umum. Rekeningrekening ini memungkinkan bank untuk menggunakan dana dengan kebijakan mereka sendiri, tanpa batasan di mana, bagaimana, atau untuk tujuan apa dana itu diinvestasikan, selama itu tidak melanggar syariah (Sundararajan, 2013).

Biasanya, unrestricted PSIA dicampur dan diinvestasikan bersama dengan dana pemegang saham dan sumber dana lain, seperti giro dalam portofolio yang sama. Dalam hal ini, bank syariah akan menerima laba dan menanggung kerugian secara proporsional dengan bagiannya dari total modal dalam usaha, dan juga mendapatkan hak atas bagian mudarib yang disepakati dari keuntungan atas bagian modal rabb al-mal (Karim, 2001; Archer \& Karim, 2006).

\section{Pengembangan Hipotesis Pengaruh blockholders terhadap pengungkapan tata kelola}

Samaha (2010) dan Grassa (2018) berpendapat bahwa struktur kepemilikan berpengaruh pada informasi pada pengungkapan tata kelola. Berdasarkan paham agency theory, sumber informasi menjadi kuat ketika informasi asimetri menjadi sebuah hal yang penting antara blockholder dan pemegang saham minoritas. Jensen dan Meckling (1976) berpendapat bahwa blockholder diharapkan memiliki kekuatan dan dorongan yang lebih besar untuk memantau manajemen karena kekayaan mereka dijamin oleh kinerja keuangan perusahaan. Kepemilikan yang tersebar meningkatkan potensi konflik antara pemegang saham terbesar dengan pemegang saham minoritas (Fama \& Jensen, 1983). Selain itu, keberadaan blockholder bisa menambahkan informasi asimetri antara blockholder dan pemegang 
saham minoritas (Ho dan Wong, 2001; Patelli \& Prencipe, 2007).

Sebagian besar penelitian yang dilakukan di negara berkembang berpendapat bahwa tingkat pengungkapan tata kelola berpengaruh secara negatif terhadap kepemilikan blockholder (Haniffa \& Cooke, 2002; Samaha \& Dahawy, 2011; Samaha et al., 2012). Sedangkan menurut penelitian Grassa (2018) yang dilakukan di Negara Timur Tengah berpendapat bahwa Bank di Timur Tengah dengan pemilik blockholder yang lebih rendah memiliki tingkat informasi pengungkapan tata kelola yang lebih tinggi.

Berdasarkan uraian di atas, maka hipotesis dalam penelitian ini adalah:

H1 : Blockholders berpengaruh positif terhadap tingkat pengungkapan tata kelola.

\section{Restricted Profit Sharing Investment Account (RPSIA) terhadap pengungkapan tata kelola}

Keuangan Islam pada dasarnya didasarkan pada gagasan larangan bunga dan sistem bagi hasil. Bank syariah memang harus memobilisasi dana melalui pengaturan sistem bagi hasil tersebut karena dapat meningkatkan masalah risiko moral. Menurut Archer et al. (2010), Profit Sharing Investment Accounts (PSIA) merupakan sumber utama pendanaan bank syariah. Ratarata, besaran PSIA sekitar $62 \%$ dari aset bank syariah di 12 negara di Timur Tengah dan Asia Tenggara. Beberapa penelitian sebelumnya pernah membahas adanya konflik kepentingan antara pemegang saham ekuitas dan pemegang PSIA. Tentu saja, PSIA mendorong manajer bank syariah untuk mengambil lebih banyak risiko dan mengoperasikan bank dengan modal yang lebih sedikit (Visser, 2009).

Salah satu masalah utama yang menjadi perhatian para pemegang PSIA adalah kurangnya kekuatan mereka untuk mengendalikan keterlibatan bank dalam jenis kegiatan investasi tertentu. Masalah lain terkait dengan PSIA adalah sebagian besar praktik bank syariah dalam memperlancar labanya dari waktu ke waktu yaitu dengan melakukan hedging terhadap kemungkinan pendapatan yang rendah di masa yang akan datang (Archer et al., 2010). Praktik seperti itu menghambat transparansi dan keandalan informasi yang diungkapkan dalam laporan keuangan dan sangat membatasi pengguna laporan keuangan untuk mengevaluasi posisi aktual bank syariah (Karim, 2001). Bank syariah sebagai lembaga keuangan yang berbasis ekuitas yang didominasi oleh pemegang saham ekuitas dan pemegang PSIA, sangat mudah terpapar pada risiko besar dari penarikan dana yang mengancam posisi mereka.

Berdasarkan uraian di atas, maka hipotesis dalam penelitian ini adalah:

H2 : RPSIA berpengaruh positif terhadap tingkat pengungkapan tata kelola.

\section{Metode Penelitian}

Penelitian ini merupakan penelitian deskriptif kuantitatif. Penelitian ini bertujuan untuk mengetahui pengaruh struktur kepemilikan dan struktur dana pihak ketiga terhadap pengungkapan tata kelola pada perbankan syariah di Indonesia. Data yang digunakan dalam penelitian ini adalah data sekunder. Populasi penelitian ini adalah seluruh bank syariah di Indonesia. Metode pemilihan sampel dalam penelitian ini menggunakan sampel jenuh. Metode analisis data menggunakan statistik deskriptif, uji asumsi klasik dan uji hipotesis. Untuk melakukan uji asumsi klasik atas data sekunder ini, maka peneliti melakukan uji normalitas, uji heteroskedastisitas, dan uji autokorelasi. Uji hipotesis yang akan dilakukan dalam penelitian ini adalah Koefisien Determinasi, Uji Statistik t dan Uji Statistik F. Uji asumsi klasik dilakukan sebelum pengujian hipotesis yang terdiri dari uji normalitas, autokorelasi, multikolinieritas, dan heteroskedastisitas. Uji normalitas dilakukan untuk menguji adanya kontribusi variabel independen terhadap variabel dependen atau tidak dalam model regresi. Uji normalitas dapat dilihat dengan menggunakan metode Kolmogorov-Smirnov (K-S). Uji autokorelasi dilakukan untuk mengetahui apakah dalam model regresi terdapat korelasi antara kesalahan pengganggu pada serangkaian data observasi yang diuraikan waktu (time series) dan individu (cross section). Untuk menguji ada atau tidaknya autokorelasi, dari data residual terlebih dahulu dihitung nilai statistik Durbin-Watson(D-W). Uji Multikolinieritas dilakukan untuk menguji apakah pada model regresi variabel independen berkorelasi satu dengan yang lainnya. Metode analisis untuk menguji terjadinya multikolinieritas dapat dilihat dari hasil nilai tolerance value atau Variance Inflation Factor (VIF). uji heteroskedastisitas dilakukan untuk menguji apakah dalam model regresi ada varian dari residual yang berbeda yang dapat membiaskan hasil yang telah dihitung. Untuk mendeteksi ada tidaknya pelanggaran heteroskedastisitas, dapat dilihat dengan menggunakan metode scatter plot.

\section{Definisi Operasional Variabel}

Variabel dependen dalam penelitian ini adalah pengungkapan tata kelola. Pada penelitian ini, pengungkapan tata kelola diukur menggunakan hasil skoring dari pengungkapan Islamic Corporate Governance (ICG) yang terdiri dari 4 dimensi dan 37 indikator berdasarkan kesesuaian pelaksanaan aspekaspek ICG oleh bank syariah dengan faktor-faktor penilaian yang telah ditetapkan dalam PBI No. 11/33/PBI/2009, peneliti menyesuaikan Pedoman Good Governance Bisnis Syariah (GGBS) tahun 2011 yang diatur oleh $\mathrm{KNKG}$

Dalam penelitian ini yang menjadi variabel independen struktur kepemilikan yang diproksikan dengan Blockholders dan struktur dana pihak ketiga yang diproksikan dengan Restricted Profit Sharing Investment Account (RPSIA). Pengukuran blockholders dalam penelitian ini menggunakan rumus sebagai berikut:

Blockholders $=5 \% \times$ kepemilikan saham

Sedangkan untuk RPSIA, pengukurannya menggunakan rumus sebagai berikut:

$$
\text { RPSIA }=\frac{\text { mudharabah }}{\text { total aset }}
$$

Agar hubungan antara variabel dependen dan variabel indpenden tidak dipengaruhi oleh faktor luar 
yang tidak diteliti, maka digunakan beberapa variabel kontrol. Variabel kontrol dalam penelitian ini yaitu Unrestricted Profit Sharing Investment Account (UPSIA) dan ukuran Kantor Akuntan Publik (KAP). Dalam menentukan nilai UPSIA digunakan rumus:

$$
\text { UPSIA }=\frac{\text { tabungan, giro, deposito }}{\text { total aset }}
$$

Ukuran KAP diukur dengan variabel dummy tergabungnya KAP dengan Big 4 atau tidak. Jika KAP tergabung dengan Big 4, maka sama dengan 1, jika tidak sama dengan 0 .

\section{Analisis Data}

Dalam penelitian ini, analisis data yang digunakan adalah model regresi linier berganda. Model regresi linier berganda ini digunakan untuk mengetahui pengaruh struktur kepemilikan dan struktur dana pihak ketiga terhadap pengungkapan tata kelola. Alat analisis dalam penelitian ini menggunakan SPSS. Model persamaan regresi yang digunakan adalah sebagai berikut :

Keterangan:

$$
Y=a+\beta_{1} X_{1}+\beta_{2} X_{2}+\beta_{3} X_{3}+\beta_{4} X_{4}
$$

a : Konstanta

$\mathrm{Y} \quad$ : Islamic Corporate Governance (ICG)

$\mathrm{X}_{1} \quad$ : Blockholders

$\mathrm{X}_{2} \quad$ : Restricted Profit Sharing Investment Account (RPSIA)

$\mathrm{X}_{3} \quad$ : Unrestricted Profit Sharing Investment Account (UPSIA)

$\mathrm{X}_{4} \quad$ : Ukuran Kantor Akuntan Publik (KAP)

$\mathrm{b}_{1}-\mathrm{b}_{4} \quad$ : Koefisien regresi

\section{Hasil dan Pembahasan Statistik Deskriptif}

Statistik deskriptif variabel-variabel dalam penelitian ini dapat dilihat pada tabel 1 sebagai berikut:

Tabel 1. Hasil Analisis Statistik Deskriptif

\begin{tabular}{|l|l|l|l|l|l|}
\hline & $\mathrm{N}$ & $\begin{array}{l}\text { Mini } \\
\text { mum }\end{array}$ & $\begin{array}{l}\text { Maxim } \\
\text { um }\end{array}$ & Mean & $\begin{array}{l}\text { Std. } \\
\text { Deviation }\end{array}$ \\
\hline $\begin{array}{l}\text { Blockhol } \\
\text { ders }\end{array}$ & 77 & 36958 & $\begin{array}{l}23635 \\
56998\end{array}$ & $\begin{array}{l}36279 \\
0153\end{array}$ & $\begin{array}{l}6932540 \\
93.5\end{array}$ \\
\hline RPSIA & 77 & .001 & .009 & .005 & .003 \\
\hline UPSIA & 77 & .488 & .885 & .762 & .101 \\
\hline $\begin{array}{l}\text { Ukuran } \\
\text { KAP }\end{array}$ & 77 & 0 & 1 & .52 & .49 \\
\hline ICG & 77 & .39 & .92 & .69 & .017 \\
\hline $\begin{array}{l}\text { Valid N } \\
\text { (listwise) }\end{array}$ & 77 & & & & \\
\hline
\end{tabular}

Sumber: Data diolah

Berdasarkan tabel di atas dapat dilihat bahwa angka rata-rata pengungkapan ICG pada 11 Bank Syariah di Indonesia pada tahun 2012-2018 adalah 0,69 atau sebesar $69 \%$. Hal tersebut menunjukkan bahwa rata-rata pengungkapan ICG yang dilakukan oleh Bank Syariah yang dijadikan sampel tergolong baik dari total komponen ICG yang menjadi perhitungan indeks ICG pada penelitian ini. Di dalam pengungkapan Islamic Corporate Governance (ICG) yang terdapat 37 sub item pengungkapan, artinya rata-rata setiap perusahaan perbankan mengungkapkan 26 sub item dari 37 sub item yang ada. Nilai minimum yang didapatkan sebesar 0,39 dan nilai maksimalnya adalah 0,92 . Sedangkan untuk nilai standar deviasinya adalah 0,017 .

Variabel bebas yang pertama yaitu struktur kepemilikan yang diproksikan oleh blockholders mendapatkan nilai rata-rata sebesar 362790153. Nilai minimum untuk blockholders adalah 36958 dan nilai maksimumnya sebesar 2363556998. Untuk nilai standar deviasinya sebesar 693254093,5. Nilai rata-rata sebesar 362790153 dapat diartikan blockholders pada bank syariah telah terkonsentrasi struktur kepemilikan.

Variabel bebas yang kedua yaitu struktur dana pihak ketiga yang diproksikan dengan Restricted Profit Sharing Investment Account (RPSIA). Nilai rata-rata yang didapatkan sebesar 0,005. Nilai tersebut menunjukkan bahwa bank-bank syariah dalam sampel memiliki RPSIA yang terkonsentrasi. Selain itu, nilai minimum dan maksimum untuk RPSIA adalah sebesar 0,001 dan 0,009 dengan standar deviasi sebesar 0,003.

Variabel kontrol yang pertama yaitu Unrestricted Profit Sharing Investment Account (UPSIA). Di mana didapatkan nilai minimum sebesar 0,488 dan nilai maksimum sebesar 0,885 dengan rata-rata sebesar 0,762 dan standar deviasi sebesar 0,101. Variabel kontrol yang kedua adalah ukuran KAP didapatkan nilai minimum dan maksimum masing-masing sebesar 0 dan 1 dengan ratarata bernilai 0,52 dan nilai standar deviasi sebesar 0,49.

\section{Hasil Uji Asumsi Klasik}

Berdasarkan hasil uji normalitas dengan menggunakan Kolmogorov-Smirnov (K-S) diperoleh variabel residual lebih besar dari 0,05 yaitu dengan melihat nilai signifikansi bernilai 0,818 yang menunjukan bahwa data yang digunakan memiliki sebaran yang normal. Dengan kata lain asumsi normalitas data terpenuhi.

Hasil uji multikolinearitas menunjukkan bahwa masing-masing variabel mempunyai nilai tolerance lebih dari 0,10 dan nilai Variance Inflation Factor (VIF) kurang dari 10. Nilai tolerance dari blockholders, RPSIA, UPSIA, dan ukuran KAP adalah 0,640, 0,994, 0,826, dan 0,652 . Sedangkan nilai VIF $1,563,1,006,1,211$, dan 1,535. Hal ini menunjukan bahwa tidak ditemukan adanya korelasi yang kuat di antara variabel bebas, sehingga asumsi multikolinieritas data terpenuhi.

Hasil uji heteroskedastisitas dilihat melalui grafik scatter plot. Dari gambar di bawah terlihat bahwa titiktitik yang diperoleh membentuk pola acak tidak beraturan serta menyebar di atas dan di bawah angka nol (0) pada sumbu Y, sehingga dalam model regresi yang akan dibentuk tidak ditemukan adanya pelanggaran heteroskedastisitas, dengan kata varians residual bersifat homokedastisitas. 


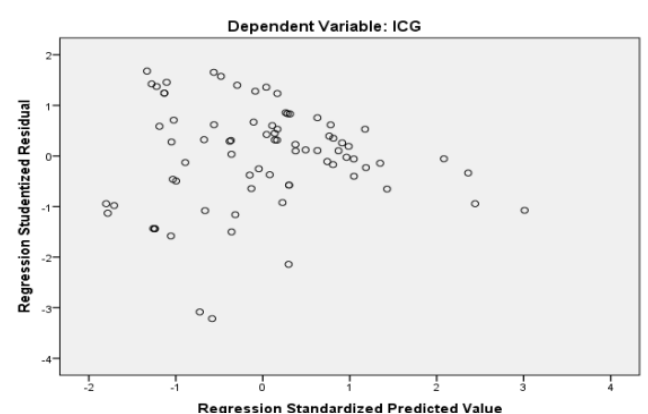

Sumber: Data diolah

Gambar 1. Hasil Uji Heteroskedastisitas

Hasil uji autokorelasi dengan uji Durbin-Watson menghasilkan nilai sebesar 2,132. Sedangkan nilai dL sebesar 1,515 dan nilai dU sebesar 1,739. Sesuai dengan kriteria pengujian bahwa tidak ditemukan adanya pelanggaran autokorelasi baik itu autokorelasi positif maupun autokorelasi negatif.

\section{Hasil Analisis Regresi Linier Berganda}

Tabel 2. Hasil Uji Regresi Linier Berganda

\begin{tabular}{|c|c|c|c|c|c|c|}
\hline \multicolumn{7}{|c|}{ Coefficients $^{\mathrm{a}}$} \\
\hline \multirow{2}{*}{\multicolumn{2}{|c|}{ Model }} & \multicolumn{2}{|c|}{$\begin{array}{l}\text { Unstandardized } \\
\text { Coefficients }\end{array}$} & \multirow{2}{*}{$\begin{array}{c}\begin{array}{c}\text { Standardized } \\
\text { Coefficient }\end{array} \\
\text { Beta }\end{array}$} & \multirow[t]{2}{*}{$\mathrm{T}$} & \multirow[t]{2}{*}{ Sig. } \\
\hline & & B & $\begin{array}{c}\text { Std. } \\
\text { Error }\end{array}$ & & & \\
\hline \multirow[t]{5}{*}{1} & (Constant) & 69.825 & 7.906 & & 8.832 & .000 \\
\hline & Blockholders & 1.083 & .343 & .341 & 3.157 & .002 \\
\hline & RPSIA & 1176.438 & 294.030 & .347 & 4.001 & .000 \\
\hline & UPSIA & -35.575 & 10.055 & -.337 & -3.538 & .001 \\
\hline & Ukuran KAP & 8.777 & 2.750 & .342 & 3191 & .002 \\
\hline
\end{tabular}

Sumber: Data diolah

Berdasarkan hasil pengujian dengan metode regresi linier berganda di atas, pengungkapan ICG memiliki nilai konstanta sebesar 69,825. ketika keempat variabel bebas bernilai nol (0) dan tidak ada perubahan, maka pengungkapan ICG diprediksi akan bernilai sebesar 69,825 kali. Dengan demikian, persamaan regresi linier berganda yang akan dibentuk adalah sebagai berikut: $\mathrm{Y}=69,825+1,083 \mathrm{X}_{1}+11176,438 \mathrm{X}_{2}-35,575 \mathrm{X}_{3}+$ $8,777 \mathrm{X}_{4}$

\section{Hasil Uji Hipotesis}

\section{Hasil Uji Koefisien Determinasi}

Hasil uji koefisien determinasi diperoleh angka $\mathrm{R}^{2}$ sebesar 0,461 atau 46,1\%. Hal ini menunjukan bahwa blockholders dan RPSIA memberikan kontribusi terhadap pengungkapan ICG pada Perbankan Syariah di Indonesia sebesar $46,1 \%$, sedangkan sisanya sebesar 53,9\% lainnya merupakan kontribusi dari variabel lain yang tidak diteliti. Berikut tabel hasil pengujian koefisien determinasi:

Tabel 3. Hasil Uji Koefisien Determinasi

\begin{tabular}{|l|l|l|c|c|c|}
\hline \multicolumn{7}{|c|}{ Model Summary $^{\mathbf{b}}$} \\
\hline Model & $\mathrm{R}$ & $\begin{array}{c}\mathrm{R} \\
\text { Square }\end{array}$ & $\begin{array}{c}\text { Adjusted } \\
\mathrm{R} \\
\text { Square }\end{array}$ & $\begin{array}{c}\text { Std. Error } \\
\text { of the } \\
\text { Estimate }\end{array}$ & $\begin{array}{c}\text { Durbin- } \\
\text { Watson }\end{array}$ \\
\hline 1 & $.679^{\mathrm{a}}$ & .461 & .431 & 9.73290 & 2.132 \\
\hline \multicolumn{2}{|l}{ a. Predictors: (Constant), Ukuran KAP, UPSIA, RPSIA, } \\
Blockholders \\
\hline b. Dependent Variable: ICG \\
Sumber: Data diolah
\end{tabular}

Hasil Uji Statistik F (Uji Simultan)

Hasil uji statistik F dapat dilihat pada Tabel 4 di bawah ini:

Tabel 4. Hasil Uji Statistik F

\begin{tabular}{|c|c|c|c|c|c|c|}
\hline \multicolumn{7}{|c|}{ ANOVA $^{\mathrm{a}}$} \\
\hline \multicolumn{2}{|c|}{ Model } & $\begin{array}{l}\text { Sum of } \\
\text { Squares }\end{array}$ & df & $\begin{array}{c}\text { Mean } \\
\text { Square }\end{array}$ & $\mathrm{F}$ & Sig. \\
\hline \multirow[t]{3}{*}{1} & Regression & 5837.683 & 4 & 1459.421 & 15.406 & $.000^{\mathrm{b}}$ \\
\hline & Residual & 6820.510 & 72 & 94.729 & & \\
\hline & Total & 12658.193 & 76 & & & \\
\hline \multicolumn{7}{|c|}{ a. Dependent Variable: ICG } \\
\hline \multicolumn{3}{|c|}{$\begin{array}{l}\text { b. Predictors:(Constant), } \\
\text { Blockholders }\end{array}$} & & KAP, & PSIA, & PSIA, \\
\hline
\end{tabular}

Sumber: Data diolah

Berdasarkan hasil perhitungan di atas, terlihat bahwa nilai F-hitung yang diperoleh sebesar 15,406 dan nilai signifikansi sebesar 0,000 yang lebih kecil dari nilai alfa sebesar 0,05. Artinya, secara simultan kedua variabel bebas yang terdiri dari blockholders dan RPSIA berpengaruh signifikan terhadap pengungkapan tata kelola pada Perbankan Syariah di Indonesia.

\section{Hasil Uji Statistik t}

Hasil uji statistik t dapat dilihat pada Tabel 2. Berdasarkan Tabel 2 di atas, diketahui bahwa nilai thitung yang diperoleh blockholder sebesar 3,157 dengan nilai signifikansi sebesar 0,002 yang lebih kecil dari alpha $(\alpha)$ sebesar 0,05 sehingga dapat disimpulkan bahwa sesuai dengan kriteria pengujian hipotesis bahwa $\mathrm{H}_{0}$ ditolak dan $\mathrm{H}_{\mathrm{a}}$ diterima, artinya secara parsial blockholders berpengaruh positif signifikan terhadap pengungkapan tata kelola pada Perbankan Syariah di Indonesia. Berdasarkan Tabel 2, diketahui bahwa nilai t-hitung yang diperoleh RPSIA sebesar 4,001 dengan nilai signifikansi sebesar 0,000 yang lebih kecil dari alpha $(\alpha)$ sebesar 0,05 sehingga dapat disimpulkan bahwa sesuai dengan kriteria pengujian hipotesis bahwa $\mathrm{H}_{0}$ ditolak dan $\mathrm{H}_{\mathrm{a}}$ diterima, artinya secara parsial RPSIA berpengaruh positif signifikan terhadap pengungkapan tata kelola pada Perbankan Syariah di Indonesia.

\section{Pembahasan}

\section{Pengujian Pengaruh Struktur Kepemilikan terhadap Pengungkapan Tata Kelola}

Berdasarkan hasil penelitian yang dilakukan oleh penulis, dapat disimpulkan bahwa struktur kepemilikan berpengaruh signifikan terhadap pengungkapan tata kelola. Di mana nilai t-hitung yang diperoleh sebesar $3,157>$ t-tabel 1,666. Sesuai dengan kriteria pengujian hipotesis bahwa $\mathrm{H}_{0}$ ditolak dan Ha diterima, artinya secara parsial blockholders berpengaruh positif signifikan terhadap pengungkapan tata kelola pada Perbankan Syariah di Indonesia. Adanya pengaruh signifikan antara struktur kepemilikan dan pengungkapan tata kelola secara parsial mengindikasikan bahwa struktur kepemilikan dalam penelitian ini yaitu blockholders merupakan faktor yang dibutuhkan untuk menghasilkan pengungkapan tata kelola yang tinggi.

Dengan kata lain, hasil penelitian ini mendukung teori dari Jensen dan Meckling (1976) yang 
mengungkapkan bahwa pemegang saham substansial diharapkan memiliki kekuasaan dan insentif yang lebih besar dalam memonitor manajemen, karena kesejahteraan mereka terkait erat dengan kinerja keuangan perusahaan. Penelitian ini juga sejalan dengan hasil penelitian yang dilakukan oleh Puspitaningrum dan Atmini (2012) yang mengatakan bahwa blockholder ownership yang tinggi oleh beberapa pemegang saham dapat dianggap sebagai pengawasan, sehingga dapat membatasi terjadinya masalah keagenan (agency problem). Jenis pemantauan oleh pemegang saham diyakini untuk mendorong para manajer dalam meningkatkan kinerja dan menjalankan perusahaan dengan cara yang lebih transparan, sehingga dapat membatasi terjadinya masalah keagenan (agency problem).

Hasil penelitian ini juga sesuai dengan penelitian Chau dan Gray (2002) serta Huafang dan Jianguo (2007) yang menemukan bukti bahwa kepemilikan blockholder berpengaruh positif terhadap pengungkapan. Hapsoro (2007) mengemukakan bahwa isu corporate governance di negara-negara Asia termasuk Indonesia memiliki struktur kepemilikan terkonsentrasi. Sanchez, et al. (2011) mengemukakan bahwa kepemilikan saham yang terkonsentrasi tinggi akan berusaha mewujudkan keselarasan kepentingan dengan shareholders yang lain dengan cara melalui pengendalian yang superior terhadap dewan komisaris sebagai orang yang mewakili para pemegang saham untuk memantau operasional perusahaan sehingga akan menciptakan penekanan yang tinggi pula terhadap pihak manajemen. Ketika tekanan dan pengawasan semakin ketat dan efektif maka akan berdampak pada semakin membaiknya pula kinerja manajemen termasuk menjaga transparansi dan mendorong manajemen mewujudkan keterbukaan informasi.

\section{Pengaruh Dana Pihak Ketiga terhadap Pengungkapan Tata Kelola}

Berdasarkan hasil penelitian yang dilakukan oleh penulis, dapat disimpulkan bahwa RPSIA berpengaruh signifikan terhadap pengungkapan tata kelola. Di mana nilai t-hitung yang diperoleh sebesar 4,001 > t-tabel 1,666. Sesuai dengan kriteria pengujian hipotesis bahwa $\mathrm{H}_{0}$ ditolak dan $\mathrm{H}_{\mathrm{a}}$ diterima, artinya secara parsial RPSIA berpengaruh positif signifikan terhadap pengungkapan tata kelola pada Perbankan Syariah di Indonesia. Adanya pengaruh signifikan antara RPSIA dan pengungkapan tata kelola secara parsial mengindikasikan bahwa Dana Pihak Ketiga dalam penelitian ini yaitu RPSIA merupakan faktor yang dibutuhkan untuk menghasilkan pengungkapan tata kelola yang tinggi.

Bank Syariah yang berstruktur modal dari ekuitas yang didominasi oleh ekuitas pemegang saham dan pemegang RPSIA sangat mudah terpapar risiko besar penarikan dana yang mengancam posisi mereka masingmasing. Bank Syariah meningkatkan pengungkapan mereka untuk mempertahankan pemegang RPSIA. Hasil penelitian ini sejalan dengan studi Magalhaes dan AlSaad (2013) yang menunjukkan bahwa mayoritas bank syariah percaya bahwa laporan keuangan yang diaudit secara triwulanan dengan penjelasan terperinci tentang setiap item adalah informasi yang cukup untuk pemegang RPSIA.

Penelitian yang dilakukan Grassa (2018) juga menunjukkan hasil yang sama yaitu adanya hubungan positif dan signifikan antara RPSIA dengan pengungkapan tata kelola. Di mana, tingkat pengungkapan bank syariah akan meningkat apabila konsentrasi PSIA pada bank syariah lebih tinggi.

\section{Kesimpulan}

Penelitian ini bertujuan menguji pengaruh variabel struktur kepemilikan dan struktur dana pihak ketiga terhadap pengungkapan tata kelola. Berdasarkan hasil analisis yang telah dilakukan, maka dapat disimpulkan bahwa struktur kepemilikan yang diproksikan dengan blockholders berpengaruh positif signifikan terhadap pengungkapan tata kelola yang diproksikan dengan Islamic Corporate Governance (ICG). Struktur dana pihak ketiga yang diproksikan dengan Restricted Profit Sharing Investment Account (RPSIA) juga berpengaruh positif signifikan terhadap pengungkapan ICG.

Dalam penelitian ini masih terdapat beberapa keterbatasan yang sebaiknya perlu dilakukan perbaikan pada penelitian-penelitian yang lebih lanjut. Beberapa keterbatasan tersebut antara lain: (1) Pemilihan variabel independen dalam penelitian ini hanya dilihat dari dua variabel saja dengan dua variabel kontrol. Diharapkan penelitian selanjutnya dapat menambah variabel independen lain yang mungkin dapat mempengaruhi pengungkapan ICG. (2) Jumlah sampel yang digunakan dalam penelitian ini masih terlalu sedikit, yaitu hanya 11 bank syariah. Saran untuk penelitian selanjutnya adalah memperluas jumlah sampel seperti meneliti bank syariah di negara lain.

\section{Daftar Pustaka}

Adiono, C. L., \& Sholihin, M. 2014. Analisis Pengungkapan Tata Kelola Bank Syariah di Indonesia. Jurnal Keuangan dan Perbankan Vol.18 No.2 , 268-277.

Allegrini, M., \& Greco, G. 2013. Corporate boards, audit committees and voluntary disclosure: Evidence from Italian listed companies. Journal of Management and Governance, 17(1), 187-216.

Archer, S., \& Karim, R. 2006. On Capital Structure, Risk Sharing and Capital Adequacy in Islamic Banks. International Journal of Theoretical and Applied Finance, Vol. 9 No. 3, 269-280.

Archer, S., \& Karim, R. A. 2009. Profit-sharing investment accounts in Islamic banks: Regulatory problems and possible solutions. Journal of Banking Regulation Volume 10 Issue 4, 300-306.

Archer, S., Karim, R., \& Sundararajan, V. 2010. Supervisory, regulatory, and capital adequacy implications of profit sharing investment accounts in Islamic Finance. Journal of Islamic Accounting and Business Research, Vol. 1 No. 1, 10-31. 
Ardhanareswari, R. 2017. Pelaksanaan dan Pengungkapan Good Corporate Governance Pada Bank Umum Syariah. Jurnal Law and Justice Vol.2 No.1, 66-78.

Arief, T. 2019. Terjadi Empat Internal Fraud di BJB Syariah Selama 2018. https://finansial.bisnis.com/. 24 Mei 2019.

Arifin, Z. 2006. Dasar-dasar Manajemen Bank Syariah. Jakarta: Pustaka Alvabet.

Armereo, C. (2015). Analisis Faktor-Faktor yang Mempengaruhi Profitabilitas Bank Syariah yang Terdaftar di Bursa Efek Indonesia Indonesia. Jurnal Ilmiah Ekonomi Global Masa Kini, 6(2), 48-56.

Baderi, F. 2018. Perbankan Syariah Kinerja yang Buruk Akibat Tata Kelola. http://www.neraca.co.id. Maret 2019.

Badriyah, L. 2018. Perbankan Syariah: Kinerja yang Buruk karena Tata Kelola. http://infobanknews.com. 27 Februari 2019.

Barnhart, S. W., \& Rosenstein, S. 1998. Board Composition, Managerial Ownership, and Firm Performance: An Empirical Analysis. The Financial Review. 33 (4), 1-16.

Bhuiyan, M., \& Biswas, P. 2007. Corporate Governance And Reporting: An Empirical Study Of The Listed Companies In Bangladesh. Journal Of Business Studies Vol. XXVIII No.1.

Boediono. 2005. Pengaruh Mekanisme Corporate Governance Terhadap Manajemen Laba dan Dampaknya pada Kualitas Laba. Jurnal Akuntansi Vol. IX No. 3, 232-244.

Chapra, M., \& Ahmed, H. 2002. Corporate Governance in Islamic Financial Institutions. Islamic Development Bank-Islamic Research and Training Institute 3(6), 58-180.

Chau, G., \& Gray, S. 2002. Ownership Structure and Corporate Voluntary Disclosure in Hong Kong and Singapore. The International Journal of Accounting Vol.37 No.2, 247-265.

Chau, G., \& Gray, S. 2010. Family ownership, board independence and voluntary disclosure: Evidence from Hong Kong. Journal of International Accounting Auditing and Taxation, 19(2), 93-109.

Cicilia, S. 2017. Bank BJB Klaim Terapkan GCG di Unit Syariah. https://keuangan.kontan.co.id. Maret 2019.

CNN. 2018. Bank Syariah Mandiri Diduga Beri Pembiayaan Fiktif Rp 1,1 T. https://www.cnnindonesia.com. Mei 2019.

Elasrag, H. 2014. Corporate Governance in Islamic Finance: Basic Concepts and Issues. SSRN.

El-Hawary, D., Grais, W., dan Iqbal, Z. 2004. Regulating Islamic Financial Institusions: The Nature of The Regulated. World Bank Policy Research Working Paper 3227.

El Junusi, R. 2012. Implementasi Shariah Governance Serta Implikasinya Terhadap Reputasi Dan Kepercayaan Bank Syariah. Al-Tahrir: Jurnal Pemikiran Islam, Vol. 12, No. 1: 87-111.

Eliana, E., \& Wahyuni, D. (2019). Pengaruh Implementasi Corporate Governance terhadap
Efisiensi Bank Umum di Indonesia. Jurnal Ilmiah Ekonomi Global Masa Kini, 10(2), 111-118.

Eng, L., \& Mak, Y. 2003. Corporate Governance and Voluntary Disclosures. Journal of Accounting and Public Policy Vol.2 No.4, 325-345.

Fama, E., \& Jensen, M. 1983. Separation of Ownership and Control. Journal of Law and Economics Vol.26, No.2, 301-325.

Ferdyant, F., Z.R., R. A., \& Takidah, E. 2014. Pengaruh Kualitas Penerapan Good Corporate Governance dan Risiko Pembiayaan terhadap Profitabilitas Perbankan Syariah . Jurnal Dinamika Akuntansi dan Bisnis Vol.1, No.2 , 134-149.

Gambling, T., \& Karim, R. A. 1991. Business and Accounting Ethics in Islam. London: Mansell Publishing.

Ghozali, I. 2016. Aplikasi Analisis Multivariete Dengan Program IBM SPSS 23 (Edisi 8) Cetakan ke VIII. Semarang: Badan Penerbit Universitas Diponegoro.

Grassa, R. 2016. Ownership Structure, Deposits Structure, Income Structure and Insolvency Risk in GCC Islamic Banks. Journal of Islamic Accounting and Business Research 7 (2), 93-111.

Grassa, R. 2018. Deposits Structur, Ownership Concentration, and Corporate Governance Disclosure in GCC Islamic Banks. Journal of Islamic Accounting and Business Research, 1-28.

Gunarsih, T. 2003. Struktur Kepemilikan Sebagai Salah Satu Mekanisme Corporate Governance. Kompak No.8, 155-172.

Hafiyyan. 2018. Peringkat Asean Corporate Governance, Rangking RI Didorong 5 Emiten. https://market.bisnis.com. Juni 2018.

Haniffa, R., \& Cooke, T. 2002. Culture, Corporate Governance and Disclosure in Malaysian Corporations. Abacus Vol.38 No.3, 317-347.

Hartini, Y. C. 2016. Dampak Struktur Kepemilikan dan Corporate Governance Terhadap Profitabilitas Bank. Jurnal Ekonomi Volume 7 Nomor 1, 22-33.

Hasan, Z. 2009. Corporate Governance: Western And Islamic Perspectives. International Review of Business Research Papers, Vol. 5, No. 1: 277-293.

Ho, S., \& Wong, K. 2001. Study of the Relationship between Corporate Governance Structure and the Extent of Voluntary Disclosure. Journal of International Accounting, Auditing and Taxation, 10, 139-156.

Hossain, M. 2008. The Extent of Compliance of Corporate Governance Disclosure: Evidence from Indian Banking Companies. Corporate Ownership and Control 5(4), 440-451.

Hudart, S. 1993. The Effect of A Large Shareholder on Corporate Value. Management Science Vol.39.

IFSB. 2006. Guiding principles on corporate governance for institutions (other than insurance institutions) offering only Islamic financial services. Kuala Lumpur: Islamic Financial Services Board.

Jensen, M. C., \& Meckling, W. H. 1976. Theory of The Firm: Managerial Behavior, Agency Cost, and 
Ownership Structure. Journal of Financial Economics, Vol. 3, No. 4, 305-360.

Jiang, H., \& Habib, A. 2009. The Impact of Different Types of Ownership Concentration on Annual Report Voluntary Disclosure in New Zealand. Accounting Research Journal Vol.22 No.3, 275-304.

Jiang, H., Habib, A., \& Hu, B. B. 2011. Ownership Concentration, Voluntary Disclosure and Information Asymmetry in New Zealand. The British Accounting Review Vol.43 Issue 1, 39-53.

Karim, A. A. 2010. Bank Islam. Jakarta: PT RajaGrafindo Persada .

Karim, R. 2001. International Accounting Harmonization, Banking Regulation, and Islamic Banks. The International Journal of Accounting, Vol. 36 No. 2, 162-193.

Kasmir. 2009. Bank dan Lembaga Keuangan lainnya . Jakarta: PT. RajaGrafindo Persada.

Kusumawati, D. 2007. Profitability And Corporate Governance Disclosure: An Indonesian Study. Jurnal Riset Akuntansi Indonesia. Vol.10. No.2, 131-146.

Moataz, E. A., \& Hussainey, K. 2012. Determinants of Corporate Governance Disclosure in Saudi Companies. Journal of Economics and Management.

Muniandy, B., \& Ali, M. 2012. Development of financial reporting environment in Malaysia. Research in Accounting Regulation, 24(2), 115-125.

Nabor, M. K., \& Suardana, K. A. 2014. Pengaruh Struktur Kepemilikan dan Proprietary Cost Terhadap Pengungkapan Sukarela. E-Jurnal Akuntansi Universitas Udayana 6.1, 126-138.

Najjar, B. A., \& Ding, R. 2014. Product Market Competition and Corporate Governance Disclosure: Evidence from the UK. Economic Issues Vol. 19(1), 73-94.

Nazir, M. 2011. Metode Penelitian. Jakarta: Salemba Empat.

Nisaputra, R. 2018. GCG di Perbankan Semakin Menurun. http://infobanknews.com. Maret 2019.

Noe, R. 2002. Employee Training and Development. New York: McGraw-Hill Companies, Inc.

Nugrahanti, Y. W., \& Novia, S. 2012. Pengaruh Struktur Kepemilikan Sebagai Mekanisme Corporate Governance Terhadap Kinerja Perbankan. Jurnal Manajemen Vol.11 No.2, 151-170.

Oetari, L. R., Gustini, E., \& Tripermata, L. (2018). Pengaruh Struktur Kepemilikan Manajerial dan Kepemilikan Institusional terhadap Kebijakan Hutang Perusahaan Studi Kasus Perusahaan Manufaktur Sub Sektor Otomotif Terdaftardi Bursa Efek Indonesia. Jurnal Ilmiah Ekonomi Global Masa Kini, 8(1), 50-55.

Onasis, K., \& Robin. 2016. Pengaruh Tata Kelola Perusahaan Terhadap Nilai Perusahaan Pada Perusahaan Sektor Keuangan yang Terdaftar di BEI. Bina Ekonomi Volume 20 Nomor 1, 1-22.

Patelli, L., \& Prencipe, A. 2007. The Relationship Between Voluntary Disclosure and Independent Directors in The Presence of a Dominant
Shareholder. European Accounting Review Vol. 16 No.1, 5-33.

Patmawati, P. (2017). Pengaruhcorporate Social Responsibility Disclosure dan Good Corporate Governance terhadap Nilai Perusahaan dengan Kinerja Keuangan Sebagai Variabel Intervening. Jurnal Ilmiah Ekonomi Global Masa Kini, 8(1), 4658.

Peraturan Bank Indonesia No. 11/33/PBI/2009 Tentang Pelaksanaan GCG Bagi Bank Umum dan Unit Usaha Syariah.

https://www.bi.go.id/id/peraturan/perbankan/Pages/ PBI 71209.aspx. Februari 2018.

Prayoga, E. B., \& Almilia, L. S. 2013. Pengaruh Struktur Kepemilikan dan Ukuran Perusahaan Terhadap Pengungkapan Manajemen Risiko. Jurnal Akuntansi \& Keuangan Vol. 4, No. 1, 1-19.

Puspitaningrum, D., \& Atmini, S. 2012. Corporate Governance Mechanism And The Level Of Internet Financial Reporting: Evidence From Indonesian Companies. Procedia Economics And Finance, 2(Af), 157-166.

Rouf, M. A. 2012. The Financial Performance and Corporate Governance Disclosure A Study in the Annual Reports of Listed Companies of Bangladesh. International Journal of Economics and Business Research 17(2), 103-117.

Ruru, B. 2002. Penerapan Prinsip-Prinsip Good Corporate Governance Di Lingkungan BUMN. http://www.bumn.go.id. Maret 2019.

Saidi. 2004. Faktor-faktor yang Mempengaruhi Struktur Modal pada Perusahaan Manufaktur Go Public di BEJ Tahun 1997-2002. Jurnal Bisnis dan Ekonomi Vol.11 No.1, 44-58.

Saleh, N., Rahman, \& Hassan, M. 2009. Ownership Structure and Intellectual Capital Performance in Malaysia. Asean Academy of Management Journal of Accounting and Finance, 5 (9), 1-29.

Samaha, K. 2010. Do Board Independence and Audit Commitees Motivate Disclosure on Different Corporate Governance Information Categories in the ANnual Reports in Developing Countries? International Research Journal of Finance and Economics, Issue 57, 206-224.

Samaha, K., \& Dahawy, K. 2011. An Empirical Analysis of Corporate Governance Structures and Voluntary Corporate Disclosure in Volatile Capital Markets: the Egyptian Experience. International Journal of Accounting Auditing and Performance Evaluation, 61-93.

Samaha, K., Dahawy, K., Hussainey, K., \& Stapleton, P. 2012. The Extent of Corporate Governance Disclosure and its Determinants in a Developing Market: The Case of Egypt. Advances in Accounting, incorporating Advances in International Accounting Vol.28, Issue 1, 168-178.

Satkunasingam, E., \& Shanmugam, B. 2004. Disclosure and Governance of Islamic Banks - A Case Study of Malaysia. Journal of International Banking Regulation 6 (1), 69-81. 
Sekaran, U., \& Bougie, R. 2017. Metode Penelitian untuk Bisnis . Jakarta: Salemba Empat.

Septyan, K. 2018. Determinasi Tingkat Pengungkapan Bank Syariah di Beberapa Negara. Jurnal Akuntansi dan Keuangan Islam Volume 6(2), 127-141.

Sjahdeini, S. R. 2014. Perbankan Syariah Jakarta:Kencana.

SPS. 2018. www.ojk.go.id. 27 Februari 2019.

Suandi, A. B. 2017. Classification of profit-sharing investment accounts: a survey of financial statements of Islamic Banks in Asia. International Journal of Islamic and Middle Eastern Finance and Management, 1-19.

Sudana, I. M. 2011. Manajemen Keuangan Perusahaan . Jakarta: Erlangga.

Sudarsono, H. 2017. Analisis Pengaruh Kinerja Keuangan terhadap Profitabilitas Bank Syariah di Indonesia. Jurnal Ekonomi Islam, vol. Volume 8, pp. $175-203$.

Sugiyono. 2014. Metode Penelitian Pendidikan Pendekatan Kuantitatif, Kualitatif, dan $R \& D$. Bandung: Alfabeta.

Suhardjanto, D., \& Dewi, A. 2011. Pengungkapan Risiko Finansial dan Tata Kelola Perusahaan: Studi Empiris Perbankan Indonesia. Jurnal Keuangan dan Perbankan Vol.15 No.1, 105-118.

Sundararajan, V. 2013. Risk characteristics of Islamic products: Implications for risk measurement and supervision. Dalam S. Archer, \& R. Karim, Islamic Finance: The Regulatory Challenge (pp. 49-75). Singapore: Wiley.

Thomson, S., Pedersen, T., \& Kvist, K. 2006. Blockholder Ownership: Effects on firm value in market and control based governance system. Journal of Corporate Finance 12 , 246-269.

Cecilia, Valencia. 2018. IICD CG Award 2018 Bentuk Konsistensi Mendorong Praktik Terbaik dari GCG di Indonesia. https://ads.kontan.co.id. Juni 2019.

Visser, H. 2009. Islamic Finance: Principles and Practice. Cheltenham: Edward Elgar Publishing.

Wang, K., \& Claiborne, M. 2008. Determinants and consequences of voluntary disclosure in an emerging market: Evidence from China. Journal of International Accounting Auditing and Taxation, 17(1), 14-30.

Waryanto. 2010. Pengaruh Katakteristik Good Governance (GCG) Terhadap Luas Pengungkapan Corporate Sosial Responsibility di Indonesia. Skripsi.

Wibowo, R., \& Rohman, A. 2013. Pengaruh Governance Structure dan Fungsi Internal Control Terhadap Fee Audit Eksternal Pada Perusahaan Publik di Indonesia. Diponegoro Journal of Accounting Vol.2 No.1, 1-13.

Widiyanti, M., Jusoh, M., Md.Z.Md, \& Ismail, A. 2011. A Comparative Analysis of Corporate Governance in Indonesia and OECD. Prosiding Perkem, (pp. 4660).

World Bank. 1999. Corporate Governance: A Framework for Implementation overview.
Yanti, D. (2016). Pengaruh Kualitas Audit, Kinerja Keuangan, dan Ukuran Perusahaan terhadap Pengungkapan Good Corporate Governance pada Perusahaan LQ 45 yang Terdaftar di Bursa Efek Indonesia. Jurnal Ilmiah Ekonomi Global Masa Kini, 6(1), 1-9. 